\title{
Growth drivers of Finnish-Estonian general cargo transports
}

\author{
OLLI-PEKKA HILMOLA
}

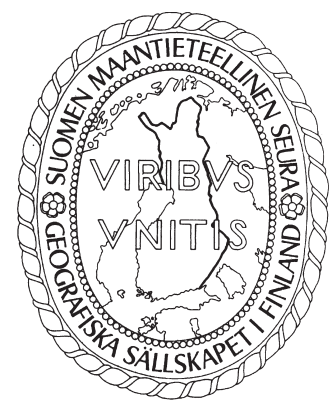

Hilmola, Olli-Pekka (2014). Growth drivers of Finnish-Estonian general cargo transports. Fennia 192: 2, pp. 100-119. ISSN 1798-5617.

Nearly the entire European trade of Finland is being executed through short sea shipping connections to Estonia, Sweden and Germany. Earlier the most important connections were to Sweden and Germany, but during Estonia's new independence era, volumes to this alternative direction have increased considerably, and are continuously growing (time alone is good proxy for growth). This cannot be said for transport flows to Sweden, and Germany also holds high uncertainty.

Based on the findings of this research, it is argued that Estonian connection growth was caused by different factors. One important factor was European Union membership in the year 2004. It should be emphasized that this was stepwise and was realized a decade ago. The main influence is that of the development of bulky trade. As measured in weight, both export and import of Finland with Estonia was found to be significant. However, in monetary terms only Finnish imports from Estonia was statistically significant. Finnish exports in turn to Estonia in value terms have contributed a negative effect (or even being insignificant). As the regression model was expanded, taking into account all three Baltic States and Poland, reliable additional findings couldn't be drawn. Completed regression analysis shows that the explanation power of GDP based models became much lower after the years 2005-2006.

Keywords: Short sea shipping, Estonia, Finland, growth, regression

Olli-Pekka Hilmola, Lappeenranta University of Technology, Kouvola Unit, Prikaatintie 9, FIN-45100 Kouvola, Finland. E-mail: olli-pekka.hilmola@lut.fi

\section{Introduction}

In the European Union truck based transportation chains are still dominating (Woxenius \& Bergqvist 2011; Morales-Fusco et al. 2012), and market shares as well as volumes have increased in the emerging East European markets (Baltic States, see Buchhofer 1995; Kovacs \& Spens 2006; Hilmola 2011). This has hardly changed after the economic crisis of 2008-2009 (Hilmola 2011). Railways have captured some share from e.g. container markets with dry port configurations (Roso et al. 2009; Rodrigue \& Notteboom 2012), but the competitiveness of rail services are still lacking behind trucks in the general cargo segment. This is mostly explained with the total lead time of transportation service, but railways are also having cost competitiveness problems over shorter distances (Reis 2014). Furthermore, railways lack the required flexibility as demand changes within short windows of time.
Short sea shipping connection is important for bulky low value exports to ensure that near-by countries could be reached within a short lead time and appropriate transportation cost level. However, even from a relatively short distance the cost disadvantage is often significant. Recent research results report that end product distribution costs from Finnish paper mills are tenfold compared to Central Europe and their locally producing paper mills (Hämäläinen 2011).

Due to globalization and competition arising from low cost countries, manufacturing in Europe has been hurt and therefore transportation logistics has emerged as one of the key components of the remaining and established factories (e.g. Asian transplants, Nieuwenhuis et al. 2012), but also as a vital part of the distribution and packaging operations of imported items (Baker 2007). It is interesting to note that e.g. between England and France freight volume forecasts made before the inauguration of the channel railway tunnel in the 
mid 1990s were the only ones, which were somewhat reliable over the following decades (Anguera 2006). Passenger transport forecasts did not hold true due to a number of reasons (e.g. end of duty free sales). Currently between England and France the channel tunnel and ro-ro/ro-pax operations of sea vessels simultaneously exist, and actually some cross ownership could be identified between the channel tunnel and short sea shipping (Groupe Eurotunnel 2013). The situation is similar in the development of the research environment of this study, short sea shipping between Finland and Estonia (without a tunnel). Times have changed, and numerous industries have been offshored from the region, but general cargo transports by short sea shipping still continue to exist and grow. Of course short sea shipping between countries within the European Union does not only serve these respective two countries, but a larger hinterland area behind the sea port. In the case of Finland and Estonia, one third of trucks with semi-trailers have a cargo destination or origin outside of these two countries (studies made by interviewing truck drivers in 2005 and 2012; Tapaninen \& Räty 2012). During the year 2012, the Baltic States and Poland together accounted $90 \%$ from overall volume, which was a slight improvement from the year 2005 and an $87.6 \%$ share. Some minor volumes are detected to Czech Republic, Slovakia, Hungary, Ukraine, Bulgaria and even Turkey.

Prior research concerning forecasting the future demand of sea ports, or forecasting drivers of development taken place, have typically been completed with statistical regression models. These models range from fairly simple to complex. Typically on a national level (e.g. number of sea ports or one large-scale sea port) models use Gross Domestic Product (GDP) tied regression models (Lehto et al. 2006; United Nations 2007) or historical demand time series and linear regression or smoothing techniques (Fung 2002; Maloni \& Jackson 2005; Yap \& Lam 2013). However, some studies exist, which have used trade level data from import and export (Seabrooke et al. 2002; Lättilä \& Hilmola 2012), and also incorporating economic forecasts of important destination or origin countries using the sea port services (Lättilä \& Hilmola 2012). A new and additional feature in demand forecasts is the use of a simulation taking into account transportation system capacity, costs and infrastructure enlargement plans to forecast e.g. railway or road transportation use at a sea port or the capability of a system itself to deliver (Kia et al.
2002; Parola \& Sciomachen 2005; Jula et al. 2006; Sanders et al. 2007; Reis 2014).

The purpose of this research is to examine the drivers of general cargo growth of short sea shipping between Finland and Estonia. Interaction has always existed between these two countries, but after the Baltic States became independent again during late 1991 and members of the European Union (and also in the same year the military alliance, NATO) 13 years later, it is evident that the platform for growth has existed (Buchhofer 1995; Ojala et al. 2005; Kovacs \& Spens 2006; Hilmola 2011). This development coupled together with a relatively cost competitive labour market, having needed flexibility, has further fostered trade growth. Also in the most recent decade imports prospered in the Baltic States as its real estate market, both private and retail sector based, experienced a boom due to massive and inexpensive capital inflows, but it ended in a severe recession during 2009 (see Bobinaite et al. 2011; Sakiene 2011; Hilmola 2013). Motivation in this research is to study the changes occurred and possible growth factors with longitudinal data in general cargo transports. By combining two different data sources for research purposes, 16 years of general cargo data was available, starting from the year 1998 and ending in 2013 (Eurostat 2013; Finnish Transport Agency 2014). Due to limitations in explaining some factor's data (like import and export weight data), this research is analyzing with a regression analysis both for the longer time period of 1998-2013, but also the shorter time window of 2002-2013 (Finnish Customs 2014). As GDP has been an important factor in previous studies, it is included in the following regression models as one alternative driver of growth. GDP data was available from the entire longer time period (Statistics Finland 2014; Statistics Estonia 2014; Central Statistical Bureau of Latvia 2014; Statistics Lithuania 2014; Central Statistical Office of Poland 2014). Objective of this study is to reveal possible long-term growth factors on general cargo transports between Finland and Estonia. However, caution should be made in the following analysis that they are in part from a relatively short time period (especially 2002-2013), and are based on an assumption that major changes will not take place in the future. Major discontinuities in transportation logistics markets and flows are always possible, and the following analysis is limited to detect these changes as it is backward looking and based on historic data. 
This research is structured as follows: In Section 2 the logistics sector development in Estonia is being analyzed and introduced. Estonia has always been at the cross-roads of east-west and northsouth material flows, even if in the recent two decades the time period of most of the volumes have merely existed in tons within the east-west direction, and on raw material handling. However, truck based transports on the north-south axel are not insignificant, but much smaller as measured in tons. In Sections 3 and 4 general cargo volumes and trade account development from a Finnish perspective are being introduced regarding the main European Union countries and directions. This is for the reason that most of the long-distance trucking volumes on the north-south axel are originating from short sea shipping operations between Finland and Estonia, and are having a significant Finnish involvement (export of industries or import of retail and industrial items). Empirical data analysis with regression models follows in Section 5. Research is concluded in Section 6 and further avenues are being proposed.

\section{Characteristics of the Estonian logistics sector}

After the early 1990s, Estonia within a short period of time developed as an important transit route for east originating raw materials. Primarily handled product was Russian oil as this country had an immediate need to deliver for growing European markets crude oil and it lacked its own sea port infrastructure. Until 2004-2005 there was clearly a growing trend in transit oil handling, and in the best year (2004) volumes were approx. 30 million tons. Afterwards Russia was able to build up their own capacity (Koskinen \& Hilmola 2005; Henttu \& Karamysheva 2013) and enlarge it in a rather short period of time (sea port Primorsk starting in 2001 and Ust'Luga in oil handling during 2011). Currently transit oil handled through Estonia is around one third lower from peak year volumes (see Fig. 1).

From raw materials other than oil, only fertilizers and coal have had significant importance dur-

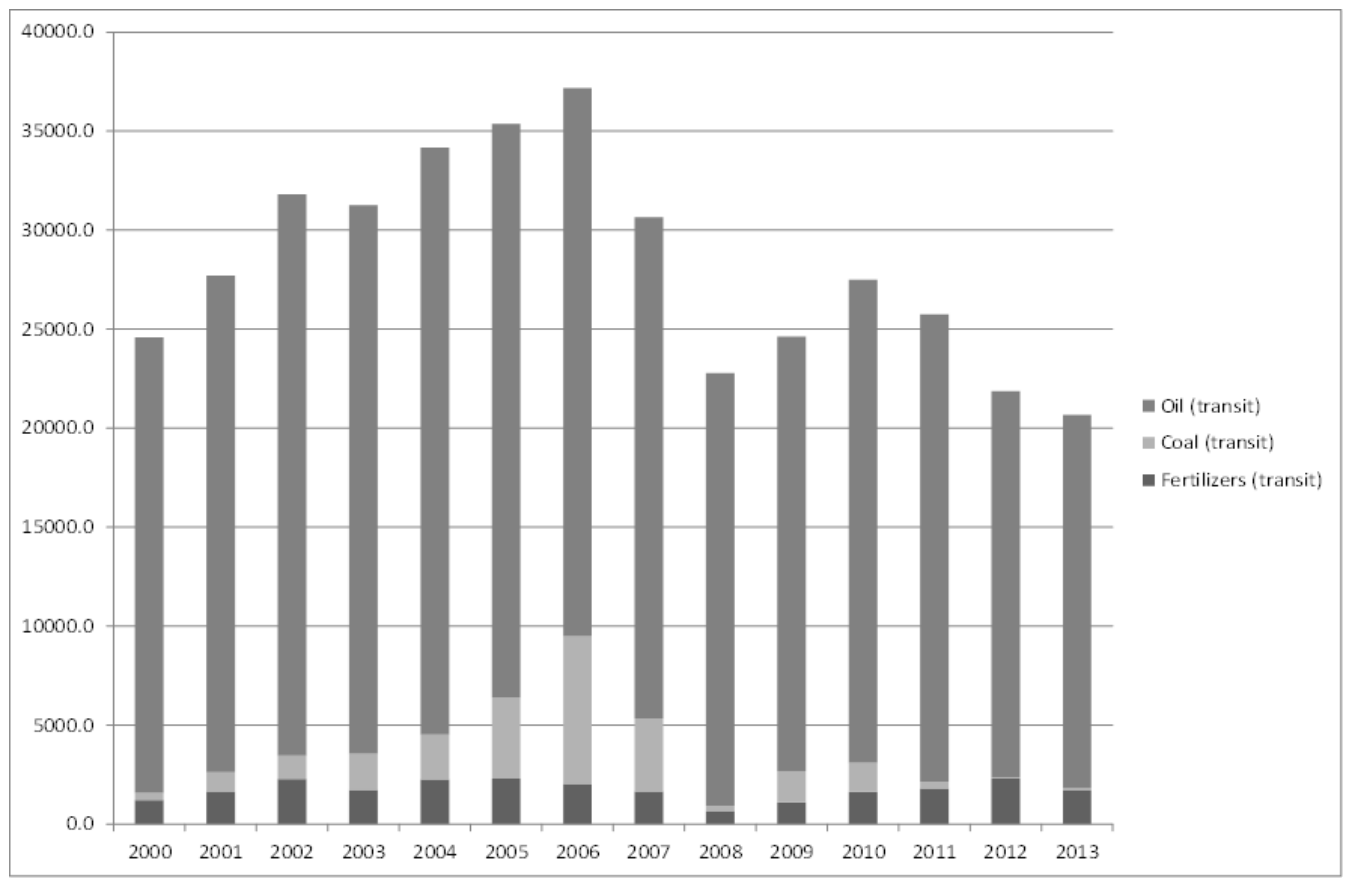

Fig. 1. Volumes of the three most important transit items of oil, coal and fertilizers in Estonian sea ports during the time period of 2000-2013 ('000 tons). Source (data): Statistics Estonia (2014), Port of Tallinn (2014). 


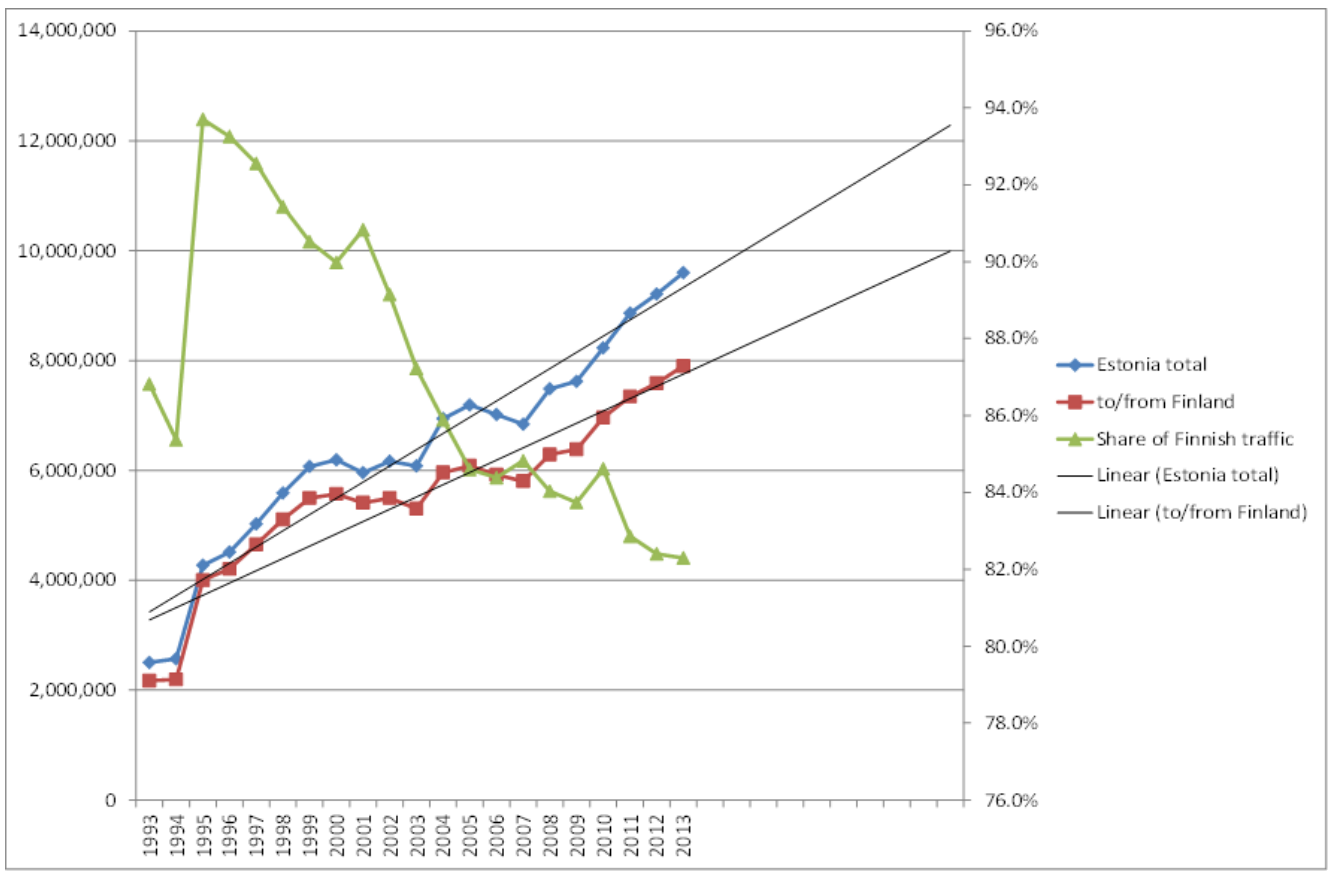

Fig. 2. Passenger transport volumes (persons) through the sea ports of Estonia and the Finnish share of it during the time period of 1993-2013, and a projection of ten years ahead with linear regression. Source (data): Statistics Estonia (2014).

ing the years (in tons). However, coal has declined very significantly from its peak of 2006 - more than 7 million tons of material handling has thereafter disappeared (99.1\% slump to the year 2013). On the positive side, fertilizers have sustained their volumes, and volumes of the years 20122013 match those of the earlier peak in 20042005.

There are a multitude of different reasons why oil and coal transit have both declined in the recent eight to nine years so much. One reason, and the main one, is the construction of Russia's own sea ports in the Gulf of Finland. These have grown in raw material handling significantly (see e.g. St. Petersburg Sea Port 2014), Primorsk in oil (approx. $75+$ million tons) and Ust'Luga both in oil (year 2013: approx. 40 mill. tons) and coal (year 2013: approx. 18 mill. tons). Secondly, other Baltic States have gained some Estonian volumes - like Latvia in coal (actually from the year 2006 the increase in Latvia's transit coal handling matches the volumes lost in Estonian sea ports; Central Statistical Bureau of Latvia 2014). Of course the political situa- tion (e.g. tensions with Russia after the bronze soldier crisis, which took place in April 2007), and the global credit crunch in the years 2008-2009 have played their role in the Estonian volume decline. It could be concluded that despite of declining volumes, the transit of raw materials remains an important product group for the Estonian logistics sector. However, today half of the material handling at sea ports is still caused by it, and most of the railway sector freight volumes are a source of it. However, Estonia cannot build up a future growth opportunity in the raw material transit, and it is a rather mature industry, but with a significant presence. Transit also enables quite many things on the infrastructure side as sea ports and railways are able to maintain certain sections from funds arising from it.

Even if transit transports has been a declining market in recent years, European Union general cargo transports (trucks and semi-trailers), container transports, private cars handled at sea ports and the amount of passengers traveling through the sea ports have all increased substantially in Estonia 
during the recent years. As ships are carrying passengers and their private cars as well as freight units simultaneously (ropax concept), it is justified to illustrate the development of passenger transport volumes (Fig. 2). As could be noted, the total visiting passengers in Estonian sea ports is currently at a level of 10 million. Finnish direction of short sea ropax ships is holding a clearly dominant role - in the year 2013 travel amounts were nearly 8 million passengers in this direction. Finnish route is still clearly following the long-term growth track and linear trend, but the trajectory to total visits is lower, and the market share is constantly falling little-by-little (currently just above $82 \%$ ).

Similar high growth could be detected from the private cars handled in the sea ports, as in the nine year period of 2005-2013 the handling amount had doubled to 1.3 million cars. For trucks and semi-trailers the development has also been upwards, not necessarily as aggressively, but still recording in the same period $59 \%$ growth, as in the year 2013 nearly 386 thousand units were handled. Finnish route market share in both of these is substantial and dominant (similar to passenger transports).

The situation with container handling is similar to earlier positive change sections of ropax shipping (but is separate from these, served with container ships). Container volumes have grown steadily, only with the exception of downwards correction during the global crisis of 2008-2009. However, the old trajectory in growth has already been reached, and during the previous decade (2004-2013) container handling volumes have more than doubled, and in the year 2013 handling amounts were above 250 thousand Twenty foot Equivalent Units (TEU). Key for growth has been container block-train service developed to connect Estonia with Moscow, Russia and other distant hinterland destinations in emerging markets of the east (EVR Cargo 2014).

\section{Finnish general cargo volumes to three main directions}

Most of the Finnish general cargo transports originating or ending in Europe is being shared between three destinations: Estonia, Sweden and Germany. This is especially the case for trucks and semi-trailers, where these three countries and their respective roro/ropax connections account for around $90 \%$ of annual handling volume. However, these markets have developed since the year 1998 rather differently (see Fig. 3). In the base period the volume of Estonian transport was really low, and Germany and Sweden dominated the general cargo market. This has drastically changed during the recent years. Sweden has been showing no or very mild growth for the entire observation period. The situation of Germany is similar, but somewhat better. Only linear and continuous growth has taken place with Estonian transport volumes, which have constantly and predictably improved over time (with the exception of the year 2009, and slight decline in the year 1999). It would not be such a big surprise, if the general cargo volumes of the Estonian connection would match those of Sweden in the very near future (couple of years). In previous research works it has been indicated that such a change would already be on the way due to Sulphur regulation becoming effective in the year 2015 (Sundberg et al. 2011; Tapaninen \& Räty 2012).

Statistical linear regression analysis was completed from Figure 3 projections, and these could be accessed from Appendix A. They reveal that Estonian growth has an extremely high statistical significance, and variance within 95\% confidence limits is low. On the average these general cargo transports will increase 175.22 thousand tons p.a., and the lower limit is just above 155 thousand tons, while the upper limit is just below 195 thousand tons. $\mathrm{R}^{2}$ value of time based model is high $(96.45 \%)$ and standard error in turn at least appropriate (165.6 thousand tons). Swedish and German regression models do not achieve any neighborhood of the level of Estonian model explanation power and have high standard errors. Actually the Swedish model is just above 0.05 level (coefficients of intercept, and annual cargo handling growth), and it is uncertain whether Swedish volumes are on the growth path in the future at all. It could be so that they have achieved some level and fluctuate around it. German general cargo is on the linear growth track as measured with statistical significance (below threshold of 0.05), but variation of annual growth is wide. On average transports ought to increase 219.71 thousand tons, but the lower limit is just above 39 thousand tons, and upper in turn slightly above 400 thousand tons. Therefore, German growth includes a high risk component involved and cannot be predicted with such high accuracy as is the case with Estonia. 


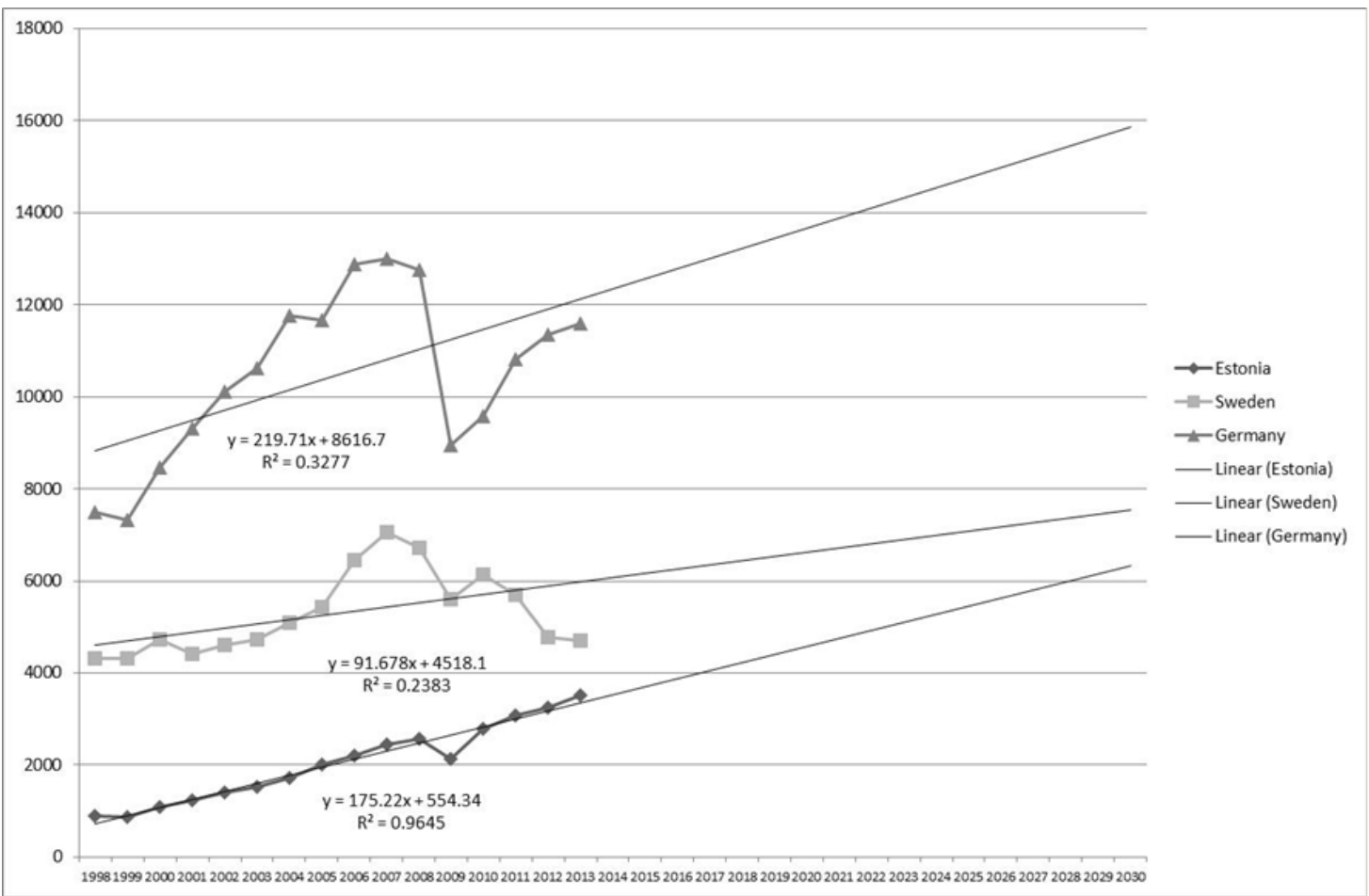

Fig. 3. General cargo volumes ('000 tons) to and from Europe (years 1998-2013) in three main shipping routes of Finland and projection of development with linear regression model up to the year 2030. Sources (data): Eurostat (2013) and Finnish Transport Agency (2014).

One component, which has been taken as a part of general cargo transports statistics (in Fig. 3), has been railway wagons carried by railships, and these have mostly served the markets of Sweden and Germany. However, both ended during the observation period, and have been one reason for uncertainty and low performance. For example, in the base year of 1998, German transports consisted of railway wagon traffic of approx. 771 thousand tons, and Sweden in turn 350.5 thousand tons. During the years volumes developed so that in the last two observation points (2012-2013) volumes approached zero. Transportation of railway wagons on a large-scale officially ended with the announcement of Finnish railway incumbent $V R$ in the year 2012 (VR Group 2011). The reason was the high losses produced and foreseen difficulties in the business environment in the future. Volumes have disappeared partly to bulk ships, containers and semi-trailers. Some traffic has also disappeared as the crisis of 2008-2009 changed structural demand a great deal in raw materials, and declining demand of e.g. paper products just continued their development after the crisis demand slump in West Europe. The last serving railship (between Finland and Sweden) is now modified as serving only trucks and semi-trailers, and it operates again on the same route (Turun Sanomat 2013), between Turku and Stockholm.

These three different routes share similarities, but also have differences. From unitized cargo (containers, trucks and semi-trailers) trucks and semi-trailers dominate Estonian and Swedish flows (Fig. 4). Actually as these two road options are added together, then both the Estonian and Swedish connections have nearly all of the transport volume on wheels (96.2\% for Estonian and 98.4\% for Swedish). German connection is more heterogeneous, and trucking share is just below $40 \%$. It should be noted that the German and Estonian routes contain numerous empty containers (returning from the north as empty), and these improve somewhat the market share of trucking as measured in tons (case of Estonia). 


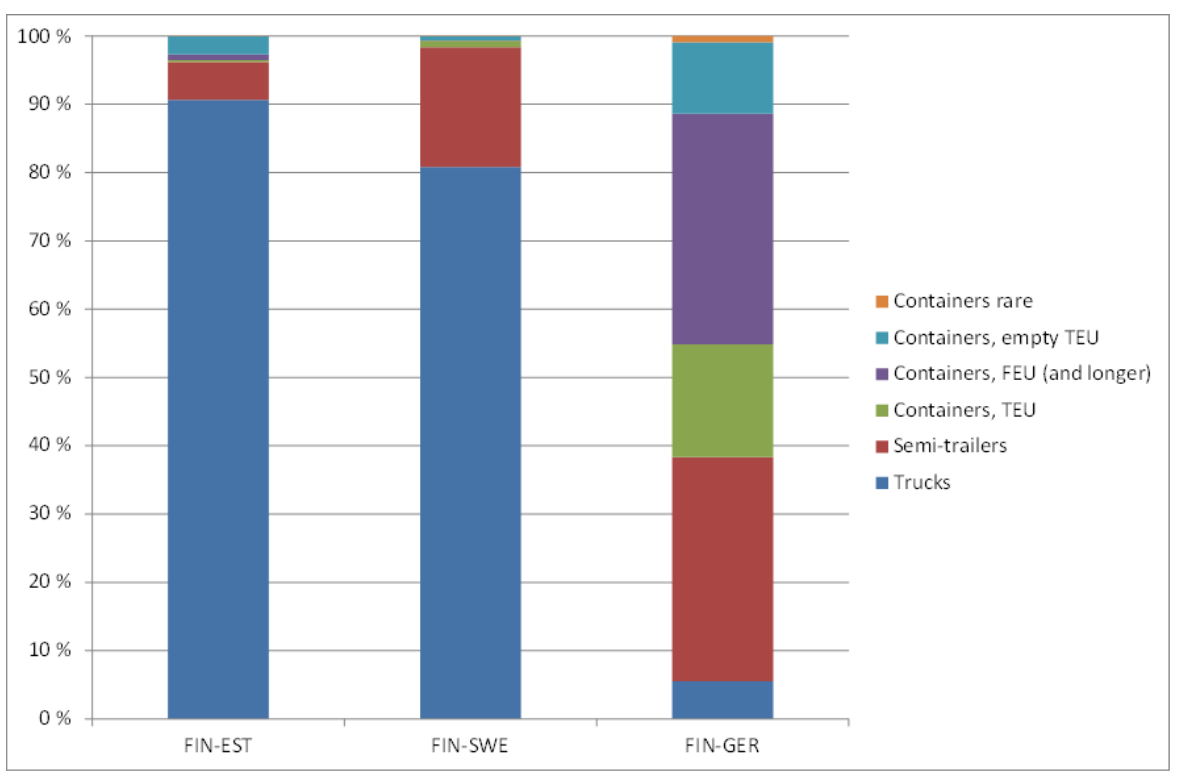

Fig. 4. European General Cargo to and from Finland on the three main shipping routes during the year 2013 (FIN-EST denotes Estonia, FIN-SWE denotes Sweden and FIN-GER in turn Germany). Source (data): Finnish Transport Agency (2014).

Although Sweden and Estonia share similarities in truck and semi-trailer dominance, unit weights are different on these routes. In the Swedish direction transportation units weigh $30-40 \%$ more. Difference is the same for Germany and semi-trailers transported - again weight is approx. $40 \%$ higher. This is of course caused by different factors, like fill-rates of transportation units, transportation volume balance in both directions, but also due to the fact that in the Baltic States restrictions for total weight on the roads are more severe as compared to Sweden (European Commission 2013).

\section{Foreign trade of Finland to three main directions}

European Union countries, and particularly those located on the periphery, have recovered in terms of trade after the major slump of the year 2009 in a rather fragile manner. This has been the case of Finland too - trade surplus was the norm before the crisis, but after the crisis initiated, in the following years' enormous trade deficits have devel- oped. This has not been caused by the great spending wave and followed imports, but merely due to a decline of exports and very small recovery of them afterwards. In the year 2013 Finnish export was still in EUR terms nearly 15\% behind the level of the year 2008. Import in turn was $6.8 \%$ lower than in the year 2008.

Similar general malaise is present in the trade accounts of Finland with Germany and Sweden, and particularly with the first mentioned (see Fig. 5). In the last observation period both of these two were producing deficits for Finland - of course the situation with Germany is really worrisome, and if the Finnish economy shall experience problems, it could be assumed that imports from Germany shall be hurt. This is simply for the reason that the deficit has been around 2 billion EUR for six consecutive years, and the total amount of the cumulative deficit after the year 2003 is more than 15.6 billion EUR. If such corrective action shall occur for imports, then it means that general cargo transports will be severely hurt.

Trade of Finland with the Baltic States and Poland has on the contrary been on a good development path - this even after the recent economic crisis. Imports to Finland from these four countries 


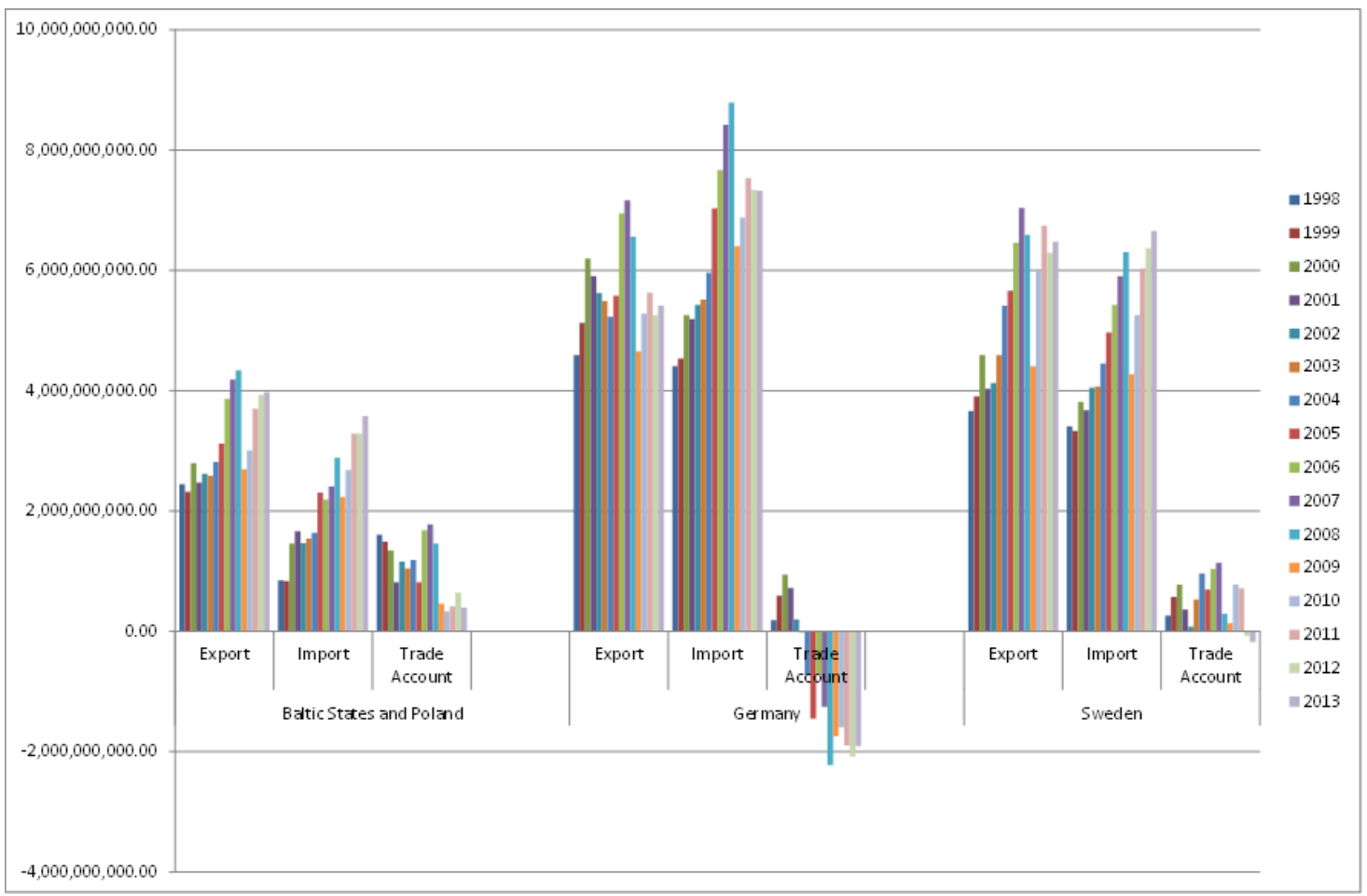

Fig. 5. Foreign trade of Finland with the Baltic States and Poland, Germany, and Sweden during the period of 1998-2013. Source: Finnish Customs (2014).

have increased almost continuously, and the year 2009 is just "normal" fluctuation around a positive development path. Finnish exports to these countries has been hurt, but has recovered, and the trade account overall is still showing a surplus.

Overall trade growth (exports plus imports) has been strongest in figure 5 within the Baltic States and Poland: From the year 1998 to 2013 it has grown nearly $130 \%$. Swedish growth is following this development with distance as growth has been in the same period roughly $60 \%$. Germany follows these two, and its trade growth is slightly over $40 \%$. It is understandable that trade growth in the emerging East European countries has been strong, but what is important, is that it still continues. The following years are important steps to be taken as trade already has substantial absolute value, and additional years of growth will correspond to very significant amounts of transportation between these countries. In the following empirical part analysis we have used this trade data from a Finnish perspective to evaluate the growth drivers of Finnish-Estonian general cargo transports.

\section{Empirical data analysis: Regression models explaining growth}

\section{Smaller and larger GDP models}

Interestingly in both of the following analyzed GDP regression models, EU membership was not found to be significant and did not have any relation to cargo growth (see Appendix B). In general the GDP model was facing difficulties to find relevant GDP series to serve a forecast of freight traffic growth between Finland and Estonia as GDPs in the region have developed so differently. For example, as measured in Polish Zlotys, GDP of Poland has consistently grown during the entire observation period, even in the global recession periods of 2001-2002 and 2008-2009. As an opposite to this, Finland grew consistently until 2009, and thereafter GDP has experienced severe growth problems. In the year 2013, Finnish GDP in absolute terms was still below the year 
2008 peak level. The Baltic States experienced high growth before the year 2009, and recorded a great slump in this global recession year, while showing a stronger recovery with a two year delay.

As noted earlier, in the smaller Finnish-Estonian GDP model, EU membership together with Finnish GDP development, were both excluded from the final regression model. Also intercept was not significant, and it was forced to be set as zero. Therefore, the only significant growth driver was Estonian GDP. This tiny regression model was able to explain freight growth in extremely good fashion $\left(R^{2}\right.$ value of 99.3), however, standard error of forecast was higher as compared to plain time based (Section 3 and Appendix A) regression model (196.1 thousand tons). As illustrated in figure 6, regression model works well until the year 2005, but thereafter overestimates general cargo demand development, and in turn after the year 2010 underestimates.
Enlarging the GDP model to consider all GDPs (Finland, Baltic States and Poland) and EU accession does not bring any better results to the earlier small GDP model. Again, GDP of Finland, Latvia and Poland is not statistically significant, and so is the case of EU membership as well. In the model, intercept is significant (and negative) as is the GDP of Lithuania. Actually explanation power of the model is lower than before $\left(\mathrm{R}^{2}\right.$ is $\left.94.8 \%\right)$, and standard error is slightly higher (207.8 thousand tons). Explanation of a high level of standard error lies in the same level as in the earlier GDP model, and after 2006 extremely good fit changed as overestimating and later underestimating freight demand.

\section{Only Estonian trade factors considered}

As data availability was a challenge for a longer period of general cargo data (years 1998-2013), both longer (1998-2013) and shorter (2002-2013) data periods were analyzed. In the longer period EU

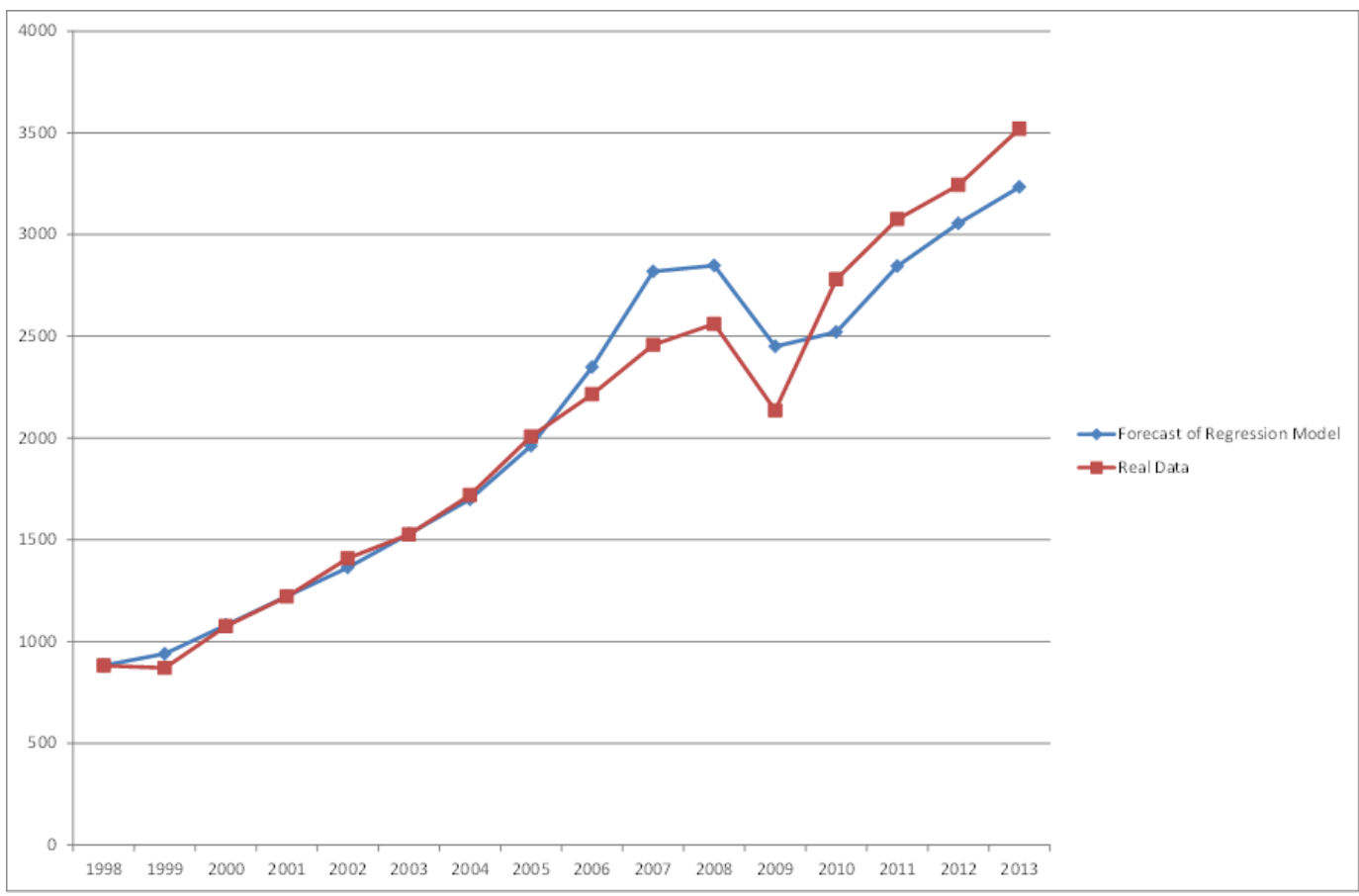

Fig. 6. Forecast using Estonian GDP regression model on freight volumes and annual real data concerning these volumes. 
membership was used as a binary factor (before 2004 and after) and Finnish export and import to Estonia in euros as absolute scale factor. In the shorter period we included the weight of exports and imports in the model as well.

Result of longer data model regression analysis is shown first in Appendix C. For the long-term regression model we were able to find a statistically significant model, where import to Finland (euros) was significant together with EU membership. Intercept co-efficient was forced to be set to zero in this model. The model itself is interesting in a way that it argues that EU membership brought a fixed amount of 767.6 thousand tons annually to the Finnish-Estonian general cargo route. However, what is also interesting, is the fact that general cargo volumes seem to be linked more on Finnish imports (other words, Estonian exports) rather than Finnish exports. It is actually difficult to link Finnish export to Estonia (in euros) to the general cargo volume growth. An export anomaly has also been detected in trade data analysis in previously published research works (Sundberg et al. 2011). Even if $R^{2}$ value is extremely high $(97.9 \%)$ in this regression model, it should be reminded that standard error is also high (345 thousand tons). Therefore, on the average model predicts in good fashion, but under- and over-estimates develop in the observation period. In comparison to plain time based model (introduced in Section 3 and Appendix A), R2 value is a bit higher, but standard error of model is roughly double. Consequently, improvement to plain time regression model is albeit very small, if built model has any benefit at all.

Even if EU membership was modeled in the regression model as binary, membership effects are not necessarily so simple. This is illustrated further in figure 7. Longer data regression model overemphasizes EU membership clearly in the years 2004-2005, but again the period of 2006-2009 matches in extremely good fashion. However, in recent years (2010-2013) the regression model underemphasizes the real cargo handling development. Maybe EU membership has had some complex endogenous and systemic changes take place in trade and/or relevance of other countries has increased in this cargo route. The global credit crunch might also have changed production and supply chain structures so drastically that more volume has appeared on route.

In the shorter data period model (Appendix C, second regression report) we were able to include import and export weight on the regression model - intercept was also having co-efficient. Model is having high $R^{2}$ value $(98.3 \%)$ and low standard error (120 thousand tons). For the longer data period model and earlier Section 3 plain time regression model, this is significantly better performance. This analysis somewhat also confirmed the finding of the longer data trade model. Surprisingly, Finnish export to Estonia (in euros) is at a significance level, but has a negative co-efficient. Regarding other factors, they have a positive co-efficient. Therefore, Finnish exports have become bulkier, where value does not increase, but volumes do and are having a positive relation to general cargo growth. Interestingly, weight factor for Finnish exports to Estonia in kilogrammes is higher than the other way around. In the model, EU membership is on the same level as earlier, approx. 711 thousand tons more general cargo was being added on the route, since membership started in the year 2004.

As the observation period was shorter and a higher number explaining the factors of FinnishEstonian trade were considered, the situation of EU membership over-emphasis right after membership started (year 2004) and correspondingly under-emphasis later on disappeared. Regression model fits extremely well to real data as shown in figure 8. It is possibly so that EU membership affected bulky trade items significantly and their movement across the two borders, instead of the trade of valuable goods. This also partly answers questions raised in figure 7 - bulky trade and its transports are the reason for the mismatch in earlier trade analysis.

\section{Larger model, where trade of the Baltic States and Poland are considered}

As the regression model is enlarged to other countries in the Finnish-Estonian transportation flow influence area, interpretation of results does not become easier. On the contrary numerous countries and four different measures applied make it an even greater challenge as explaining factors can cover each other in the regression model and show extremely high explanation values. This was the case with regression models built from the Baltic States and Poland (Appendix D). Only trustworthy and in line of previous plain Estonian models, was the import and export value model with longer data period (1998-2013), where Estonian imports to Finland together with Lithuanian import and export as well as EU membership explains $99.7 \%$ from the general cargo transports. Standard error of this model is low (127.4 thousand tons). 


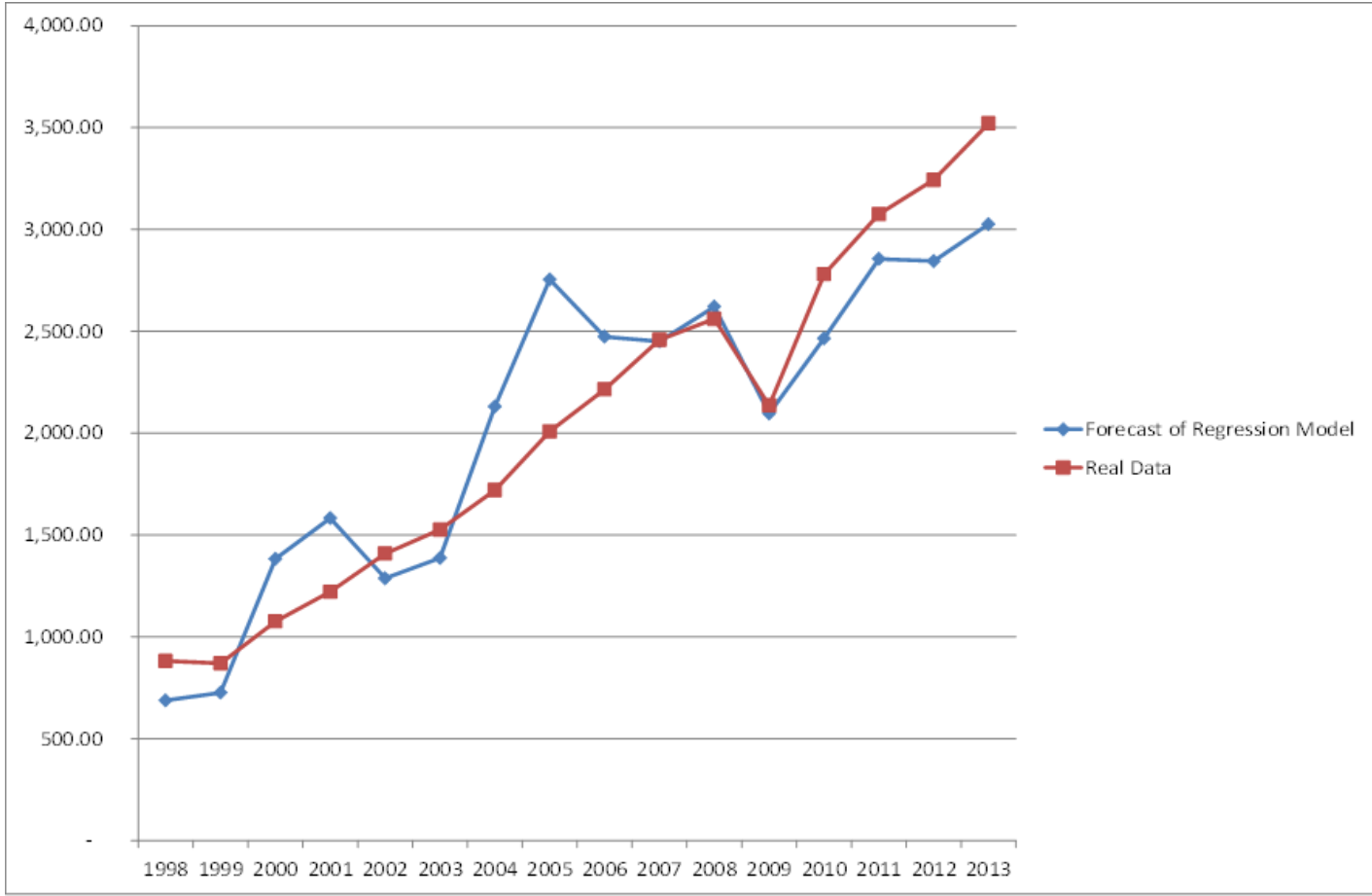

Fig. 7. Forecast using longer data regression trade model on freight volumes (FINEST 1998-2013) and annual real data concerning these volumes.

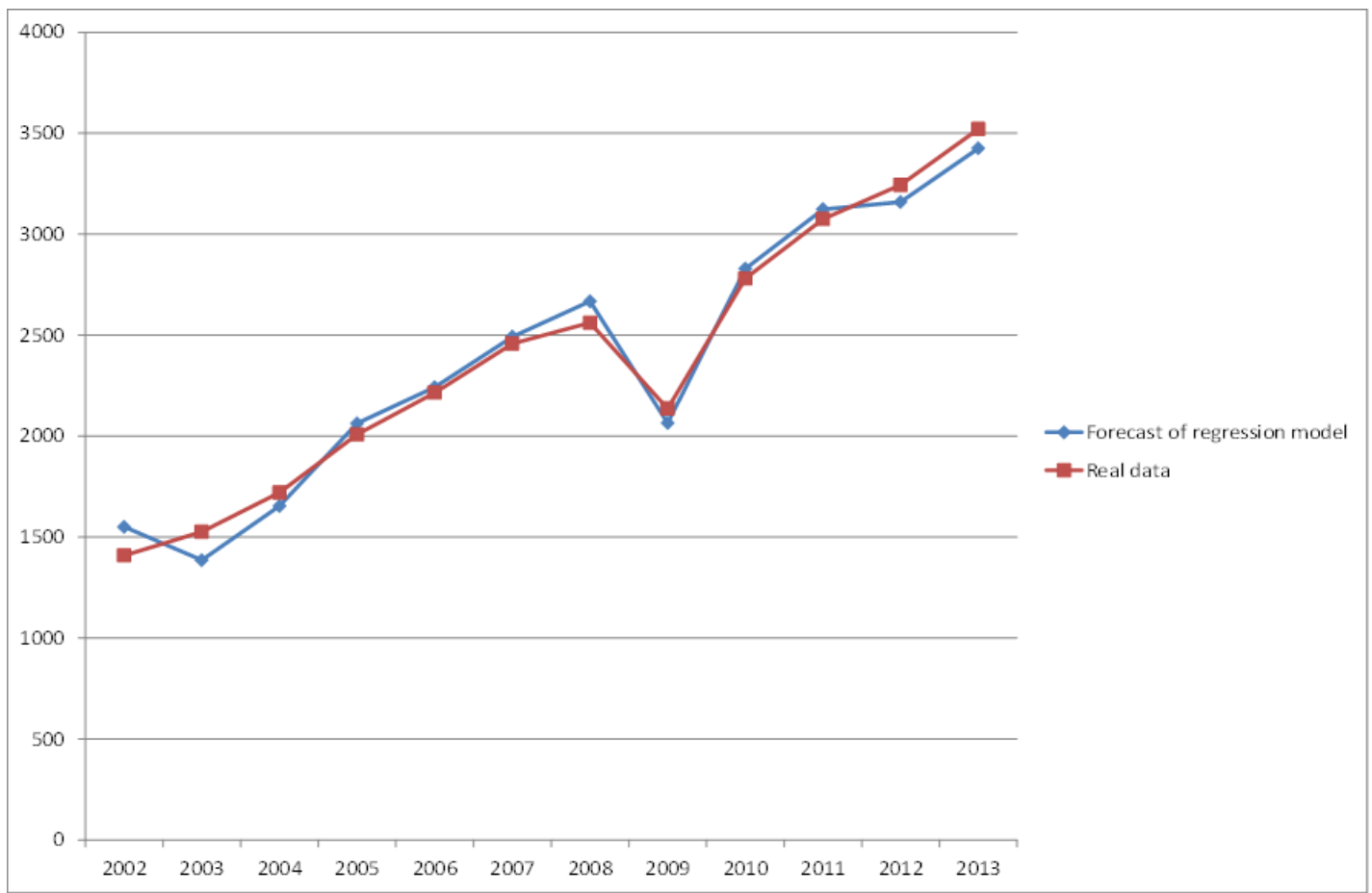

Fig. 8. Forecast using shorter data regression model on freight volumes (FINEST 2002-2013) and annual real data concerning these volumes. 
Shorter data period models were highly controversial. In the import-export value models, out of nowhere Finnish exports to Estonia became significant together with Lithuanian imports to Finland and EU membership. Maybe due to the shorter observation period and just a random occurrence of Lithuanian imports made Estonian exports from Finland fit the model. The situation is similar with the weights $(\mathrm{kg})$ of import and export trade. Numerous factors were having a negative co-efficient, like Estonian and Lithuanian imports from Finland, as well as the exports from Finland to Poland. Three other factors of import-export trade were having a positive co-efficient towards general cargo transports. We may conclude that either one of these shorter period models is valid or support earlier model findings. The only valid finding is gained from the observation that EU membership is significant even here (in one model out of two), and it gains the overall support of positively affecting transportation flows.

\section{Concluding discussion}

In the European Union area it is hard to find a similar growth area of transportation logistics, which the Finnish-Estonian short sea shipping of the general cargo group has shown over two decades. Except for the most recent economic crisis which has taken place during the years 2008-2009, and followed a transportation volume decline of $16.6 \%$, this connection has consistently grown over the years and many times by more than $10 \%$ p.a. Together with the year 2009, only the year 1999 has been slightly negative. Using just time to explain freight growth gave reasonable results in the regression analysis (Appendix A). It is even much better than conventionally used GDP based forecasting models (Appendix B). Actually from the two GDP models used in this study, Estonian GDP was shown to be a better interpreter of transportation volume growth in the studied context. However, based on the year 2014 information, Estonian GDP growth is very low in early 2014 (Q1) or slightly negative (in nominal terms somewhat growing, but constant wise on a small decline; Laarmaa 2014). Even in this situation, Finnish-Estonian transportation still continues to grow, and has even done so during the early months of 2014 (e.g. major ropax sea vessel operator Tallink has reported $20 \%$ growth in the amount of freight trucks during the first five months of 2014 as com- pared to 2013; Tallink 2014). As one result of this study is the finding that GDP alone is not an appropriate measure to forecast volume growth in this short sea shipping route, or it undervalues the trade in times of economic hardship (which Finland and the Baltic States have experienced after 2008-2009). Trade parameters and their respective development seem to yield much better forecasting results in this environment.

Based on this research work, it is clear that growth has benefitted from EU membership (year 2004 onwards) as all trade models found this to be significant. This did not only help trade between Finland and Estonia, but opened up better possibilities to integrate the whole Baltic States and Poland to the transportation and supply chains, as border formalities and custom procedures were removed from these countries. Therefore, fewer inventory points and country level operations were needed and real market integration started. This has been argued in priori membership case studies (Ojala \& Naula 2002) as well as afterwards in surveys (Hilmola 2012). Based on this study, general cargo transports between Finland and Estonia benefitted from step-wise growth of 200 up to 700 thousand tons. However, the EU membership effect is not the main finding of this study. It is the change of transported items between Finland and Estonia - towards bulky and lower value goods, especially in Finnish exports, and trade's ability to explain freight volume development.

Regarding other factors, it is hard to argue consistently against that other than Finnish-Estonian trade issues have really contributed to the growth. It is certain that Estonian imports to Finland have improved and contributed to the growth over the years. This has taken place in both value and weight. However, Finnish exports to Estonia could have been fostering transport growth, but only by weight, not in value measured terms (euros). Actually in the regression model the Finnish export value co-efficient was negative. Thus, in this trade pair the effect of weight is much more important than value overall. From outside of this two country pair, it could have been so, that Lithuanian and Finnish trade has been a contributing factor on general cargo volume growth. Furthermore in one multi-country model Latvia as well as Poland were both present, but co-efficient values were hugely controversial, and this cannot be taken as a valid finding. The situation with GDP based forecasting is controversial for Finnish-Estonian freight volumes as after the year 2006 its ability to forecast 
has been questionable and over- and understating the real demand.

Findings of this research work do not differ that much from interview studies that have taken place for truck drivers regarding cargo destination and origin in the sea ports of Helsinki and Tallinn during the years 2005 and 2012 (Tapaninen \& Räty 2012). The only major difference for this interview study is the significance of EU membership, which this study clearly showed. Tapaninen \& Räty (2012) interview study also indicated that the hinterland area has increased and currently the second largest served country is Poland. We cannot argue against any of these findings, and trade accounts and data sets values could incorporate major raw materials, which mask the importance of general cargo based trade (e.g. export of Polish coal to Finland in the 1990's and early 2000). It would require further research to incorporate only export and import product groups, which are suitable for long-distance truck transports, and not raw material transport chains based on trains and bulk ships.

As a further research it would be interesting to continue with this topic, and complete a study concerning the future growth factors of this general cargo route. In the short-term growth is in place as stiff environmental legislation is implemented at the Baltic Sea (e.g. sulphur, $\mathrm{CO}_{2}$, and nitrogen legislation), and this will make shipping and especially long-distance shipping, expensive (see Notteboom 2011). Development ought to benefit "very short" distance shipping and hinterland based transportation chains. The second natural development path is the move of factory locations within the European Union towards the east. This has taken place already for more than a decade, but based on recent observations, is a continuing trend in the future as well. A third factor possibly contributing to the future growth, is the inauguration of transportation chains, which start from the Mediterranean area and continue with the hinterlands to Northern Europe (instead of going through hubs located in the Netherlands, Belgium or Germany). All these would require a proper further research effort to clarify future growth opportunities.

\section{REFERENCES}

Anguera R 2006. The channel tunnel - an ex post economic evaluation. Transportation Research Part A 40: 4, 291-315. http://dx.doi.org/10.1016/j. tra.2005.08.009.

Baker P 2007. An exploratory framework of the role of inventory and warehousing in international supply chains. International Journal of Logistics Management 18: 1, 64-80. http://dx.doi.org/10.1108/09574090710748171.

Bobinaite V, Juozapaviciene A \& Konstantinaviciute I 2011. Regression analysis of gross domestic product and its factors in Lithuania. International Scientific Conference on Economics and Management (Brno, Czech Republic). Journal of Economics and Management 16, 116-126.

Buchhofer E 1995. Transport infrastructure in the Baltic States during the transformation to market economies. Journal of Transport Geography 3: 1, 69-75. http://dx.doi.org/10.1016/0966-6923(94)00001-6.

Central Statistical Bureau of Latvia 2014. Transport database of Latvia. <http://data.csb.gov.Iv/Menu. a s $p x$ ? $p x_{-}$I a n g u a $g$ e = e $n \& p x_{\text {_ }}$ $d b=$ transp\&rxid $=c d c b 978 c-22 b 0-416 a-a a c c-$ aa650d3e2ce0> 3/2014.

Central Statistical Office of Poland 2014. Poland macroeconomic indicators (PKD 2007). <http://stat. gov.pl/en/poland-macroeconomic-indicators/> 5/2014.

European Commission 2013. EU Transport in Figures - Statistical Pocketbook. European Commission, Belgium.

Eurostat 2013. Transport Statistics (maritime). <http:// epp.eurostat.ec.europa.eu/portal/page/portal/ transport/data/database> 9/2013.

EVR Cargo 2014. Scheduled Trains. Eesti Raudtee (EVR Cargo). Tallinn, Estonia. <http://www.evrcargo.ee/ regulaarrongid/?lang=en>3/2014.

Finnish Customs 2014. Uljas database. Helsinki, Finland. <http://uljas.tulli.fi/> March.2014.

Finnish Transport Agency 2014. Personal communication with database specialist (sea transports). February-March, 2014. Helsinki and Lappeenranta, Finland.

Fung MK 2002. Forecasting Hong Kong's container throughput: an error-correction model. International Journal of Forecasting 21: 1, 69-80. http:// dx.doi.org/10.1002/for.818.

Groupe Eurotunnel 2013. Annual Review and Corporate Social Responsibility Report. Groupe Eurotunnel, Paris.

Henttu V \& Karamysheva M (2013). Trends of freight transportation in North-West Russia in 2010s. International Journal of Procurement Management 6: 6, 666-683. http://dx.doi.org/10.1504/IJPM.2013.056761.

Hilmola O-P 2011. Rail Baltica influence area: State of operating environment. Lappeenranta University of Technology, Department of Industrial 
Management, Research Report 236. Lappeenranta, Finland.

Hilmola O-P 2012. Warehousing in Finnish and Swedish companies: State of operating environment during period of 2006-2012. Journal of Transport and Telecommunication 13: 4, 261270.

Hilmola O-P 2013. From bubble to sustainable economy in Baltic States. Journal of Transport and Telecommunication 14: 3, 237-249.

Hämäläinen E 2011. Economic geographic characteristics in the Finnish paper industry - a case study. Fennia 189: 2, 63-75.

Jula H, Chassiakos A and loannou P 2006. Port dynamic empty container reuse. Transportation Research Part E 42: 1, 43-60. http://dx.doi.org/10.1016/j.tre.2004.08.007.

Kia M, Shayan E \& Ghotb F 2002. Investigation of port capacity under a new approach by computer simulation. Computers \& Industrial Engineering 42: 2-4, 533-540.

h ttp://dx.doi.org/10.1016/S03608352(02)00051-7.

Koskinen M-M \& Hilmola O-P 2005. Investment cycles in newbuilding market of ice-strengthened oil tankers. Maritime Economics and Logistics 7: 2, 173-188.

http://dx.doi.org/10.1057/palgrave. mel.9100128.

Kovacs G \& Spens K M 2006. Transport infrastructure in the Baltic States post-EU succession. Journal of Transport Geography 14: 6, 426-336. h t t p ://dx.do i.org/10.1016/j . jtrangeo.2006.01.003.

Laarmaa A 2014. Economy decreased in the 1st quarter. Statistics Estonia, Tallinn. <http://www. stat.ee/72497> 6/2014.

Lehto H, Vepsäläinen P \& Hietala K 2006. Growth outlook of seaborne transport between Finland and foreign countries up to 2030 (in Finnish). Finnish Maritime Administration Publications 10/2006, Helsinki.

Lättilä L \& Hilmola O-P 2012. Forecasting long-term demand of largest Finnish sea ports. International Journal of Applied Management Science 4: 1, 5279.http://dx.doi.org/10.1504/IJAMS.2012.044871.

Maloni M \& Jackson EC 2005. North American container port capacity: an exploratory analysis. Transportation Journal 44: 3, 1-22.

Morales-Fusco P, Sauri S \& Lago A 2012. Potential freight distribution investments using motorways of the sea. Journal of Transport Geography 24, 1-11. http://dx.doi.org/10.1016/j.jtrangeo.2012.05.007.

Nieuwenhuis P, Beresford A \& Choi AK-Y 2012. Shipping of local production? CO2 impact on a strategic decision: An automotive industry case study. International Journal of Production Economics 140: 1, 138-148.

http://dx.doi.org/10.1016/j.ijpe.2012.01.034.
Notteboom T 2011. The impact of low sulphur fuel requirements in shipping on the competitiveness of roro shipping in Northern Europe. WMU Journal of Maritime Affairs 10: 1, 63-95. http://dx.doi. org/10.1007/s13437-010-0001-7.

Ojala L \& Naula T 2002. Advanced Logistics Services in the Baltic States (AD LOG). Tedim report, Turku.

Ojala L, Naula T \& Queiroz C 2005. Transport sector restructuring in the Baltic status as members of the European Union. Proceedings of the 3rd Seminar, Vilnius, Turku School of Economics Publications.

Parola F \& Sciomachen A 2005. Intermodal container flows in a port system network: analysis of possible growths via simulation models. International Journal of Production Economics 97: 1, 75-88. http://dx.doi.org/10.1016/j.ijpe.2004.06.051.

Port of Tallinn 2014. Cargo statistics webpage. <http:// www.portoftallinn.com/key-figures> 3/2014.

Reis V 2014. Analysis of mode choice variables in short-distance intermodal freight transport using agent-based model. Transportation Research: Part A 61, 100-120. http://dx.doi.org/10.1016/j.tra.2014.01.002.

Rodrigue J-P \& Notteboom T 2012. Dry ports in European and North American intermodal rail systems: two of a kind? Research in Transportation Economics 27: 1, 19-29.

http://dx.doi.org/10.1016/j.rtbm.2012.10.003.

Roso V, Woxenius j \& Lumsden K 2009. The dry port concept: connecting container sea ports with the hinterland. Journal of Transport Geography 17: 5, 338-345.

http://dx.doi.org/10.1016/j.jtrangeo.2008.10.008.

Sakiene H 2011. Regional unemployment regulation during economic slowdown in Lithuania. International Scientific Conference on Economics and Management (Brno, Czech Republic). Journal of Economics and Management 16, 309-315.

Sanders F, Verhaeghe RJ \& Dekker S 2007. Investment dynamics for a congested transport network with competition: application to port planning. Proceedings of the 23th International Conference of The System Dynamics Society, Boston.

Seabrooke W, Hui ECM, Lam WHK \& Wong GKC 2003. Forecasting cargo growth and regional role of the port of Hong Kong. Cities 20: 1, 51-64. http://dx.doi. org/10.1016/S0264-2751(02)00097-5.

Statistics Estonia 2014. Transport statistics database. <http://www.stat.ee/transportation> 3/2014.

Statistics Lithuania 2014. Economy and Finance (macroeconomics).<http://osp.stat.gov.It/en/ statistiniu-rodikliu-analize1> 5/2014.

St. Petersburg Sea Port 2014. Sea port throughputs. Big Port St. Petersburg, St. Petersburg, Russia. $<$ http://www.pasp.ru/dannye_po_gruzooborotu> 3/2014.

Sundberg P, Posti A \& Tapaninen U 2011. Cargo Traffic on the Helsinki-Tallinn Route. Publications from the Centre for Maritime Studies, University of Turku A56, Turku. 
Tallink 2014. Tallinn stock exchange press release database, Tallink. <http://www.nasdaqomxbaltic. $\mathrm{com} / \mathrm{market} /$ ? instrument $=E E 3100004466 \&$ list $=2$ $\&$ date $=2012-08-12 \& p g=$ details \& tab $=$ news $>$ $6 / 2014$.

Tapaninen U \& Räty P 2012. Vehicles carrying cargo in ports of Helsinki and Tallinn. In Tapaninen $U$ (ed). Helsinki and Tallinn on the Move, 49-59. HTTransPlan, Helsinki.

Turun Sanomat 2013. Junalautta Seawind palaa liikenteeseen rekkalauttana (free translation in English: "Railship Seawind returns as truck ship"). <http://www.ts.fi/uutiset/kotimaa/566222/Junala utta+Seawind+palaa+liikenteeseen+rekkalautta na> 3/2014.

United Nations 2007. Regional shipping and port development, container traffic forecast, 2007 update. UNESCAP Publications ST/ESCAP/2484.
VR Group 2011. Junalauttaliikenne Turun ja Tukholman välillä loppuu (free translation in English: "Railship traffic between Turku and Stockholm ends"). Press release, 7 October.

<http://www.vrgroup.fi/fi/vrgroup/uutishuone/ uutiset-ja-tiedotteet/junalauttaliikenne-turun-jatukholman-valilla-loppuu-071020110808/> 3/2014.

Woxenius J \& Berqvist R 2011. Comparing maritime containers and semi-trailers in the context of hinterland transport by rail. Journal of Transport Geography 19: 4, 680-688. http://dx.doi.org/10.1016/j.jtrangeo.2010.08.009. Yap WY \& Lam JSL 2013. 80 million-twenty-footequivalent-unit container port? Sustainability issues in port and coastal development. Ocean \& Coastal Management 71, 13-25. http://dx.doi. org/10.1016/j.ocecoaman.2012.10.011. 
Appendix A. Regression analysis results from general cargo handling volumes development over time.

\section{FINEST}

SUMMARY OUTPUT - FIN-Estonia (General Cargo)

\begin{tabular}{lr}
\hline \multicolumn{2}{c}{ Regression Statistics } \\
\hline Multiple R & 0.982 \\
R Square & 0.965 \\
Adjusted R Square & 0.962 \\
Standard Error & 165.569 \\
Observations & 16 \\
\hline
\end{tabular}

ANOVA

\begin{tabular}{|c|c|c|c|c|c|c|}
\hline & $d f$ & & SS & $M S$ & $F$ & Significance $F$ \\
\hline Regression & & 1 & 10439262.950 & 10439262.950 & 380.815 & $1.50009 \mathrm{E}-11$ \\
\hline Residual & & 14 & 383781.492 & 27412.964 & & \\
\hline Total & & 15 & 10823044.442 & & & \\
\hline
\end{tabular}

\begin{tabular}{lrrrrrr}
\hline & Coefficients & Standard Error & \multicolumn{1}{c}{ S Stat } & \multicolumn{1}{c}{ P-value } & \multicolumn{1}{c}{ Lower 95\% } & Upper 95\% \\
\hline Intercept & -349369.497 & 18007.870 & -19.401 & $1.62 \mathrm{E}-11$ & -387992.537 & -310746.457 \\
Year & 175.225 & 8.979 & 19.514 & $1.5 \mathrm{E}-11$ & 155.966 & 194.483 \\
\hline
\end{tabular}

\section{FINSWE}

SUMMARY OUTPUT - FIN-Sweden (General Cargo)

\begin{tabular}{lr}
\hline \multicolumn{2}{c}{ Regression Statistics } \\
\hline Multiple R & 0.488 \\
R Square & 0.238 \\
Adjusted R Square & 0.184 \\
Standard Error & 807.849 \\
Observations & 16 \\
\hline
\end{tabular}

ANOVA

\begin{tabular}{lrrrrr}
\hline & $d f$ & & \multicolumn{1}{c}{ SS } & \multicolumn{1}{c}{ MS } & \multicolumn{1}{c}{ S } \\
\hline Regressionificance $F$ \\
Residual & 1 & 2857671.468 & 2857671.468 & 4.379 & 0.055 \\
Total & 14 & 9136679.084 & 652619.935 & & \\
\hline
\end{tabular}

\begin{tabular}{lrrrrrr}
\hline & Coefficients & Standard Error & \multicolumn{1}{c}{ S Stat } & P-value & Lower 95\% & Upper 95\% \\
\hline Intercept & -178563.554 & 87864.719 & -2.032 & 0.062 & -367014.633 & 9887.525 \\
Year & 91.678 & 43.812 & 2.093 & 0.055 & -2.289 & 185.645 \\
\hline
\end{tabular}


FINGER

SUMMARY OUTPUT - FIN-Germany (General Cargo)

\begin{tabular}{lr}
\hline \multicolumn{2}{c}{ Regression Statistics } \\
\hline Multiple R & 0.572 \\
R Square & 0.328 \\
Adjusted R Square & 0.280 \\
Standard Error & 1550.868 \\
Observations & 16 \\
\hline
\end{tabular}

ANOVA

\begin{tabular}{|c|c|c|c|c|c|}
\hline & $d f$ & SS & $M S$ & $F$ & Significance $F$ \\
\hline Regression & 1 & 16412203.639 & 16412203.639 & 6.824 & 0.020 \\
\hline Residual & 14 & 33672692.564 & 2405192.326 & & \\
\hline Total & 15 & 50084896.202 & & & \\
\hline
\end{tabular}

\begin{tabular}{lrrrrrr}
\hline & Coefficients & Standard Error & \multicolumn{1}{c}{ t Stat } & P-value & \multicolumn{1}{c}{ Lower 95\% } & Upper 95\% \\
\hline Intercept & -430138.259 & 168678.317 & -2.550 & 0.023 & -791917.268 & -68359.249 \\
Year & 219.707 & 84.108 & 2.612 & 0.020 & 39.314 & 400.100 \\
\hline
\end{tabular}

Appendix B. Regression model forecasting FINEST general cargo volumes with GDP (do note that GDP of Estonia in euros and Lithuania in litas).

SUMMARY OUTPUT - GDP of Finland and Estonia (data 1998-2013)

\begin{tabular}{lr}
\hline \multicolumn{2}{c}{ Regression Statistics } \\
\hline Multiple R & 0.996 \\
R Square & 0.993 \\
Adjusted R Square & 0.926 \\
Standard Error & 196.116 \\
Observations & 16 \\
\hline
\end{tabular}

\begin{tabular}{lrcccr} 
ANOVA & \multicolumn{1}{l}{ SS } & MS & $F$ & Significance $F$ \\
\hline Regression & $d f$ & & SS & \\
Residual & 1 & $7.708 \mathrm{E}+07$ & $7.708 \mathrm{E}+07$ & $2.004 \mathrm{E}+03$ & $1.625 \mathrm{E}-16$ \\
Total & 15 & $5.769 \mathrm{E}+05$ & $3.846 \mathrm{E}+04$ & & \\
\hline
\end{tabular}

\begin{tabular}{lrrrrrr}
\hline & Coefficients & Standard Error & $t$ Stat & $P$-value & Lower 95\% & Upper 95\% \\
\hline Intercept & 0 & & & & & \\
GDP of Estonia & 0.175 & 0.004 & 44.766 & 0.000 & 0.167 & 0.184 \\
\hline
\end{tabular}


SUMMARY OUTPUT - GDP of Finland, Baltic States and Poland (data 1998-2013)

\begin{tabular}{lr}
\hline \multicolumn{2}{c}{ Regression Statistics } \\
\hline Multiple R & 0.974 \\
R Square & 0.948 \\
Adjusted R Square & 0.940 \\
Standard Error & 207.888 \\
Observations & 16 \\
\hline
\end{tabular}

ANOVA

\begin{tabular}{|c|c|c|c|c|c|}
\hline & $d f$ & $S S$ & $M S$ & $F$ & Significance $F$ \\
\hline Regression & 2 & $1.026 \mathrm{E}+07$ & $5.131 \mathrm{E}+06$ & $1.187 \mathrm{E}+02$ & 4.458E-09 \\
\hline Residual & 13 & $5.618 \mathrm{E}+05$ & $4.322 \mathrm{E}+04$ & & \\
\hline Total & 15 & $1.082 E+07$ & & & \\
\hline
\end{tabular}

\begin{tabular}{lrrrrrr}
\hline & Coefficients & Standard Error & \multicolumn{1}{c}{ Stat } & P-value & Lower 95\% & Upper 95\% \\
\hline Intercept & -113.043 & 196.164 & -0.576 & 0.574 & -536.829 & 310.743 \\
GDP of Estonia & 0.136 & 0.089 & 1.532 & 0.149 & -0.056 & 0.329 \\
GDP of Lithuania & 0.007 & 0.015 & 0.484 & 0.637 & -0.025 & 0.039 \\
\hline
\end{tabular}

Appendix C. Regression model forecasting FINEST general cargo volumes with only Estonian trade factors.

SUMMARY OUTPUT - Estonian factors (data 1998-2013)

\begin{tabular}{lr}
\hline \multicolumn{2}{c}{ Regression Statistics } \\
\hline Multiple R & 0.989 \\
R Square & 0.979 \\
Adjusted R Square & 0.906 \\
Standard Error & 345.027 \\
Observations & 16 \\
\hline
\end{tabular}

ANOVA

\begin{tabular}{|c|c|c|c|c|c|}
\hline & $d f$ & SS & $M S$ & $F$ & Significance $F$ \\
\hline Regression & 2 & 75986941.3173 & 7993470.659 & 319.156 & 0.000 \\
\hline Residual & 14 & 1666609.588 & 119043.542 & & \\
\hline Total & 16 & 77653550.905 & & & \\
\hline
\end{tabular}

\begin{tabular}{lrrrrrr}
\hline & Coefficients & Standard Error & \multicolumn{1}{c}{ t Stat } & P-value & Lower 95\% & Upper 95\% \\
\hline Intercept & 0 & & & & & \\
EU membership & 767.649 & 226.359 & 3.391 & 0.004 & 282.156 & 1253.142 \\
Estonialmport & $1.343 \mathrm{E}-06$ & $1.477 \mathrm{E}-07$ & 9.096 & $2.979 \mathrm{E}-07$ & $1.026 \mathrm{E}-06$ & $1.660 \mathrm{E}-06$ \\
\hline
\end{tabular}


SUMMARY OUTPUT - Estonian factors (data 2002-2013)

\begin{tabular}{lr}
\hline \multicolumn{2}{c}{ Regression Statistics } \\
\hline Multiple R & 0.991 \\
R Square & 0.983 \\
Adjusted R Square & 0.969 \\
Standard Error & 120.040 \\
Observations & 12 \\
\hline
\end{tabular}

ANOVA

\begin{tabular}{|c|c|c|c|c|c|}
\hline & $d f$ & SS & $M S$ & $F$ & Significance $F$ \\
\hline Regression & 5 & 4974033.049 & 994806.61 & 69.04 & 3.20992E-05 \\
\hline Residual & 6 & 86457.11 & 14409.52 & & \\
\hline Total & 11 & 5060490.16 & & & \\
\hline
\end{tabular}

\begin{tabular}{lrrrrrr}
\hline & Coefficients & Standard Error & t Stat & P-value & Lower 95\% & Upper 95\% \\
\hline Intercept & -935.11 & 257.68 & -3.63 & 0.011 & -1565.6 & -304.6 \\
EU membership & 711.18 & 129.53 & 5.49 & 0.002 & 394.2 & 1028.1 \\
EstoniaExport & $-5.069 \mathrm{E}-07$ & $1.780 \mathrm{E}-07$ & -2.85 & 0.029 & $-9.425 \mathrm{E}-07$ & $-7.125 \mathrm{E}-08$ \\
Estonialmport & $9.366 \mathrm{E}-07$ & $2.664 \mathrm{E}-07$ & 3.52 & 0.013 & $2.847 \mathrm{E}-07$ & $1.589 \mathrm{E}-06$ \\
EstoniaExports $(\mathrm{kg})$ & $9.844 \mathrm{E}-07$ & $1.543 \mathrm{E}-07$ & 6.38 & 0.001 & $6.068 \mathrm{E}-07$ & $1.362 \mathrm{E}-06$ \\
Estonialmports $(\mathrm{kg})$ & $6.254 \mathrm{E}-07$ & $1.696 \mathrm{E}-07$ & 3.69 & 0.010 & $2.103 \mathrm{E}-07$ & $1.040 \mathrm{E}-06$ \\
\hline
\end{tabular}

Appendix D. Regression model forecasting FINEST general cargo volumes with trade factors of Baltic States and Poland. SUMMARY OUTPUT - Baltic States and Poland (data 1998-2013)

\begin{tabular}{lr}
\hline \multicolumn{2}{c}{ Regression Statistics } \\
\hline Multiple R & 0.999 \\
R Square & 0.997 \\
Adjusted R Square & 0.914 \\
Standard Error & 127.387 \\
Observations & 16 \\
\hline
\end{tabular}

ANOVA

\begin{tabular}{|c|c|c|c|c|c|}
\hline & $d f$ & SS & $M S$ & $F$ & Significance $F$ \\
\hline Regression & 4 & 77458822.813 & 19364705.703 & 1193.338 & $1.99848 \mathrm{E}-14$ \\
\hline Residual & 12 & 194728.092 & 16227.341 & & \\
\hline Total & 16 & 77653550.905 & & & \\
\hline
\end{tabular}

\begin{tabular}{lrrrrrr}
\hline & Coefficients & Standard Error & $t$ Stat & P-value & Lower 95\% & Upper 95\% \\
\hline Intercept & 0 & & & & & \\
EU membership & 244.849 & 100.394 & 2.439 & 0.031 & 26.110 & 463.589 \\
Estonialmport & $4.83098 \mathrm{E}-07$ & $1.71172 \mathrm{E}-07$ & 2.822 & 0.015 & $1.10147 \mathrm{E}-07$ & $8.56049 \mathrm{E}-07$ \\
LithuaniaExport & $2.0477 \mathrm{E}-06$ & $6.25454 \mathrm{E}-07$ & 3.274 & 0.007 & $6.84952 \mathrm{E}-07$ & $3.41045 \mathrm{E}-06$ \\
Lithuanialmport & $5.37595 \mathrm{E}-06$ & $5.64775 \mathrm{E}-07$ & 9.519 & $6.09 \mathrm{E}-07$ & $4.14541 \mathrm{E}-06$ & $6.60649 \mathrm{E}-06$ \\
\hline
\end{tabular}


SUMMARY OUTPUT - Baltic States and Poland (data 2002-2013)

\begin{tabular}{lr}
\hline \multicolumn{2}{c}{ Regression Statistics } \\
\hline Multiple R & 0.999 \\
R Square & 0.999 \\
Adjusted R Square & 0.887 \\
Standard Error & 107.311 \\
Observations & 12 \\
\hline
\end{tabular}

ANOVA

\begin{tabular}{|c|c|c|c|c|c|}
\hline & $d f$ & SS & MS & $F$ & Significance $F$ \\
\hline Regression & 3 & 73368743.267 & 24456247.756 & 2123.753 & $6.084 \mathrm{E}-12$ \\
\hline Residual & 9 & 103640.205 & 11515.578 & & \\
\hline Total & 12 & 73472383.472 & & & \\
\hline
\end{tabular}

\begin{tabular}{lrrrrrr}
\hline & Coefficients & Standard Error & t Stat & P-value & Lower 95\% & Upper 95\% \\
\hline Intercept & 0 & & & & & \\
EU membership & 220.264 & 100.705 & 2.187 & 0.057 & -7.547 & 448.075 \\
EstoniaExport & $8.063 \mathrm{E}-07$ & $5.976 \mathrm{E}-08$ & 13.493 & $2.819 \mathrm{E}-07$ & $6.711 \mathrm{E}-07$ & $9.415 \mathrm{E}-07$ \\
Lithuanialmport & $6.182 \mathrm{E}-06$ & $3.969 \mathrm{E}-07$ & 15.576 & $8.129 \mathrm{E}-08$ & $5.284 \mathrm{E}-06$ & $7.080 \mathrm{E}-06$ \\
\hline
\end{tabular}

SUMMARY OUTPUT - Baltic States and Poland (data 2002-2013)

\begin{tabular}{lr}
\hline \multicolumn{2}{c}{ Regression Statistics } \\
\hline Multiple R & 0.998 \\
R Square & 0.996 \\
Adjusted R Square & 0.993 \\
Standard Error & 54.757 \\
Observations & 12 \\
\hline
\end{tabular}

ANOVA

\begin{tabular}{|c|c|c|c|c|c|}
\hline & $d f$ & SS & MS & $F$ & Significance $F$ \\
\hline Regression & 5 & $5.043 E+06$ & $1.009 \mathrm{E}+06$ & $3.364 \mathrm{E}+02$ & 2.937E-07 \\
\hline Residual & 6 & 1.799E+04 & $2.998 \mathrm{E}+03$ & & \\
\hline Total & 11 & $5.060 E+06$ & & & \\
\hline
\end{tabular}

\begin{tabular}{lrrrrrr}
\hline & Coefficients & Standard Error & \multicolumn{1}{c}{ Stat } & \multicolumn{1}{c}{ P-value } & \multicolumn{1}{c}{ Lower 95\% } & Upper 95\% \\
\hline Intercept & 2577.426 & 193.140 & 13.345 & 0.000 & 2104.830 & 3050.022 \\
PolandExports (kg) & $-3.876 \mathrm{E}-07$ & $6.034 \mathrm{E}-08$ & -6.424 & 0.001 & $-5.353 \mathrm{E}-07$ & $-2.400 \mathrm{E}-07$ \\
LithuaniaExports (kg) & $1.107 \mathrm{E}-05$ & $5.523 \mathrm{E}-07$ & 20.053 & $9.986 \mathrm{E}-07$ & $9.723 \mathrm{E}-06$ & $1.243 \mathrm{E}-05$ \\
Lithuanialmports (kg) & $-3.138 \mathrm{E}-06$ & $2.882 \mathrm{E}-07$ & -10.886 & $3.563 \mathrm{E}-05$ & $-3.843 \mathrm{E}-06$ & $-2.432 \mathrm{E}-06$ \\
Latvialmports (kg) & $3.341 \mathrm{E}-07$ & $6.024 \mathrm{E}-08$ & 5.546 & 0.001 & $1.867 \mathrm{E}-07$ & $4.815 \mathrm{E}-07$ \\
Estonialmports (kg) & $-6.795 \mathrm{E}-07$ & $9.582 \mathrm{E}-08$ & -7.091 & 0.000 & $-9.140 \mathrm{E}-07$ & $-4.450 \mathrm{E}-07$ \\
\hline
\end{tabular}

